\title{
Kelayakan Aspek Materi dan Media dalam Pengembangan Bahan Ajar Bola Voli Berbasis Kontekstual
}

\author{
Didik Hariyanto ${ }^{a}$, Moh. Ali Mu'arifuddin ${ }^{b}$ \\ ${ }^{\mathrm{a}, \mathrm{b}}$ Prodi PJKR IKIP Budi Utomo, Malang \\ *Corresponding author: hariyantod88@gmail.com; aliamzeta@gmail.com
}

\begin{tabular}{l} 
A R T I C L E I N F O \\
\hline Article history: \\
Received 30 Nopember 2017 \\
Received in revised form 25 Februari \\
2018 \\
Accepted 18 Maret 2018 \\
Keywords: \\
Textbook, Volleyball
\end{tabular}

\section{Pendahuluan}

Pemutakhiran kurikulum dalam perguruan tinggi harus selalu dilakukan dalam rangka menyesuaikan dengan perkembangan iptek yang sangat pesat, tentunya hal tersebut juga berimbas pada bahan ajar yang digunakan termasuk komponen isi mata kuliah. Kurikulum adalah seperangkat rencana dan pengaturan mengenai tujuan, isi, dan bahan pelajaran serta cara yang digunakan sebagai pedoman penyelenggaraan kegiatan pembelajaran untuk mencapai tujuan pendidikan tertentu (Muslich, 2009).

Pendidikan jasmani pada dasarnya merupakan sebuah kegiatan pendidikan yang bertujuan untuk mencapai tujuan pendidikan melalui aktivitas fisik (Bajuri, 2016). Pembelajaran akan semakin maksimal dalam mencapai tujuan yang diharapkan apabila didukung dengan materi dan bahan ajar yang lengkap sesuai dengan kondisi pembelajaran yang dilaksanakan. peningkatan mutu pendidikansangat diperlukan.

Penggunaan sarana prasarana tidak dapat dipungkiri menjadi salah satu sarana media penunjang para peserta didik dalam lebih memahami materi pelajaran yang diajarkan (Dhias, 2013). Ketersediaan sarana dan prasarana tentunya juga berpengaruh terhadap hasil dari pembelajaran yang dilakukan.

Tantangan kemajuanteknologi dan arus globalisasi menuntut para pendidik untuk dapat menghasilkan siswa sebagai sumber daya manusia yang memiliki pengetahuan tinggi dan keterampilan agar mampu menjawab tantangan tersebut (Anita, 2008). Pembelajaran yang baik yang didukung dengan media pembelajaran yang baik diharapkan mampu membentuk sumberdaya yang memiliki daya saing tinggi.

Sumber belajar (salah satunya buku ajar) pada lingkungan pendidikan tinggi wajib disediakan, difasilitasi, atau dimiliki oleh perguruan tinggi sesuai dengan program studi yang dikembangkan (UURI, 2012).

Bola voli merupakan permainan olahraga beregu yang dimainkan oleh dua tim yang saling berlawanan (Prastowo, 2011). Permainan bola voli merupakan suatu permainan yang kompleks yang tidak mudah untuk dilakukan setiap orang (Rosdiani, 2013).

Pada permainan bola voli regu yang lebih dulu mendapat nilai 25 dinyatakan sebagai pemenang pada set itu danpermainan menggunakan sistem rally point (Mutohir, 2012). Matakuliah Teori dan Praktik Bola Voli merupakan Salah satu matakuliah wajib dalam program studi pendidikan Jasmani 
Kesehatan dan. Rekresi di IKIP Budi Utomo Malang. Sebelum dilaksanakan pengembangan buku ajar Teori dan Praktik Bola Voli, sudah terdapat buku ajar yang disusun oleh tim dosen pengampu mata kuliah tersebut. Setelah dilakukan analisa sebagai analisis kebutuhan hasil uji perorangan dan kelompok kecil sebesar $80,55 \%$ dan 78,96\%. Data tersebut menunjukkan buku ajar yang telah ada termasuk dalam kategori valid dan layak digunakan, namun beberapa responden menjelaskan buku ajar yang sudah ada memiliki banyak kelemahan, .

Menurut responden, buku ajar matakuliah Teori dan Praktik Bola Voli yang telah disusun memiliki beberapa kelemahan yaitu bahan ajar cetak tidak didukung dengan bahan ajar multimedia, materi yang terdapat didalam buku ajar bersifat abstrak dan tidak dilengkapi dengan latihan-latihan serta evaluasi yang sesuai, serta tidak terdapat kegiatan laboratorium.

Buku ajar sangat bermanfaat digunakan dalam pembelajaran (Anggela, 2013). Oleh karena itu sangat penting untuk selalu mengadakan perbaikan dan pembaharuan terhadap bahan ajar yang digunakan disesuaikan dengan kebutuhan mahasiswa. Bahan ajar yang belum dikembangkan perlu mendapat perhatian khusus (Widyartono 2010).

Penyusunan bahan secara manual belum mampu mengatasi masalah dalam pembelajaran yang dialami peserta didik. Kondisi tersebut sangat memerlukan adanya perbaikan buku ajar cetak yang sudah disusun tentunya diperbaiki secara menyeluruh dan mengembangkannya menjadi buku ajar cetak yang didampingi bahan ajar multimedia interaktif.

Mengembangkan sebuah bahan ajar sebaiknya memperhatikan materi yang dibahas secara keilmuan, materi yang dikaji sesusai dengan perkembangan terbaru oleh karena itu Buku yang dihasilkan juga merupakan karya ilmiah tebaru bagi penulis. Karya ilmiah adalah karya tulis yang penyusunan dan penyajiannya didasarkan pada kajian ilmiah dan cara kerja ilmiah (Ifadah, 2009).

Hasil analisis kebutuhan ke dua dengan penyebaran angket kepada mahasiswa Program Studi Pendidikan Jasmani Kesehatan dan Rekreasi IKIP Budi Utomo Malang yang telah menempuh matakuliah Teori dan Praktik Bola Voli menunjukkan bahwa kesulitan yang dihadapi selama menempuh matakuliah Bola Voli diantaranya kurangnya pemahaman terhadap konsep/ materi $(42,85 \%)$, kurangnya didukung sarana dan prasarana lengkap $(19,04 \%)$, kegiatan praktik pembelajaran voli yang kurang $(33,33 \%)$, dan keterbatasan sumber belajar yang dimiliki mahasiswa $(4,76 \%)$. Bahan ajar yang digunakan mahasiswa selama mengikuti perkuliahan antara lain makalah, buku, dan sumber belajar dari internet. Sebagian besar dari jumlah keseluruhan mahasiswa $(73,33 \%)$ menyatakan bahwa adanya bahan ajar berbasis kontekstual sangat diperlukan sebagai penunjuang pelaksanaan perkuliahan Teori dan Praktik Bola Voli.

Penelitian ini bertujuan untuk menghasilkan buku ajar cetak yang layak ditinjau dari aspek kelayakan materi dan media

\section{Metode}

Penelitian pengembangan ini menggunakan model pengembangan yang dikemukakan oleh Thiagarajan dengan tahapan-tahapan define, design, develop, dan disseminate (4D).

penelitian menggunakan prosedur dengan tahapan meliputi tahap define, design, dan develop. Pada tahap define, dilakukan analisis kebutuhan instruksional yang diperlukan untuk pengembangan buku ajar yang meliputi langkah-langkah: (1) menganalisis kompetensi dasar matakuliah Teori dan Praktik Bola Voli II, (2) mengidentifikasi sarana prasarana dan permasalahan pembelajaran, (3) mengidentifikasi kelemahan dan kekurangan buku ajar yang telah dikembangkan, serta (4) melaksanakan penyebaran angket analisis kebutuhan ke mahasiswa Program Studi Pendidikan Jasmani Kesehatan dan Rekreasi yang telah menempuh matakuliah Teori dan Praktik Bola Voli II.

Tahap design dilakukan untuk menghasilkan draft awal buku ajar cetak edisi revisi untuk matakuliah Teori dan Praktik Bola Voli II. Tahap ini dilakukan melalui langkah berikut. (1) Penyusunan tes acuan patokan. Tes acuan patokan digunakan untuk menilai substansi dan struktur bahan ajar yang akan dikembangkan. Hasilnya berupa lembar validasi dan lembar uji keterbacaan. (2) Pemilihan format buku ajar cetak disesuaikan dengan kriteria komponen buku ajar yang disesuaikan dengan analisis kebutuhan pada tahap define.

Tahap develop bertujuan untuk merevisi draft awal buku ajar cetak dan multimedia interaktif yang telah disusun pada tahap design. Revisi didasarkan oleh proses validasi yang dilakukan oleh ahli media (ahli bahan ajar), dan ahli materi. Validator masingmasing merupakan ahli di bidangnya dengan kualifikasi pendidikan minimal S3 dan 
berpengalaman minimal 5 tahun di bidangnya.

Dalam pelaksanaan pengembangan media pembelajaran, dalam hal ini buku ajar, tahap validasi oleh ahli atau pakar menjadi tahap yang sangat penting (Safitri dan Hartati, 2016). Pada tahapan develop menggunakan model pengembangan 4D, bahan ajar yang telah dikembangkan harus melalui tahap validasi ahli yang membidangi bahan ajar tersebut. Aspek dalam bahan ajar yang harus divalidasi atau diuji kelayakannya antara lain adalah aspek materi dan media.

Instrument yang digunakan dalam pengumpulan data antara lain: angket analisisi kebutuhan dan lembar validasi bahan ajar oleh ahli media. Pengumpulan data dilaksanakan antara bulan Februari hingga Juli 2016. Tahap-tahap pengumpulan data antara lain: penyebaran angket analisis kebutuhan ke mahasiswa Program Studi Pendidikan Jasmani Kesehatan dan Rekreasi IKIP Budi Utomo yang Telah menempuh matakuliah Teori dan Praktik Bola Voli II; analisis dokumen matakuliah (RPS); mengidentifikasi kelemahan buku ajar cetak Teori dan Praktik Bola Voli II versi sebelumnya; penyusunan bahan ajar; serta proses validasi oleh ahli.

Data yang telah dikumpulkan dianalisis dengan menggunakan statistic deskriptif.

Hasil yang diperoleh dari rumus di atas akan dirujuk ke kriteria kelayakan bahan ajar (Tabel I) untuk mengetahui kelayakan produk bahan ajar.

TABEL I

Kriteria Kelayakan Buku Ajar Cetak

\begin{tabular}{ll}
\hline Skala (\%) & Kriteria Kelayakan \\
\hline $85-100$ & layak dengan predikat sangat bagus \\
$65-84$ & layak dengan predikat bagus \\
$45-64$ & layak dengan predikat cukup \\
$0-44$ & tidak layak \\
\hline
\end{tabular}

\section{Hasil Penelitian dan Pengembangan}

Hasil pengembangan bahan ajar berupa dua komponen yaitu buku ajar cetak dan multimedia interaktif. Komponen buku ajar cetak terdiri atas bagian pendahuluan, isi, dan penutup. Bagian pendahuluan terdiri atas cover, halaman sampul, prakata, daftar isi, kompetensi dasar, dan petunjuk penggunaan buku ajar. Bagian isi terdiri atas $5 \mathrm{bab}$, dan tiap bab berisi judul bab, kompetensi dasar, peta konsep, uraian materi, tugas proyek, soal evaluasi, dan kolom refleksi diri. Bagian penutup terdiri atas riwayat hidup penulis.
Bahan ajar melalui proses validasi materi dan media yang melibatkan ahli media dan teknologi pembelajaran, serta ahli materi.

Hasil penilaian masing-masing validator dihitung persentase masing-masing aspek validasi untuk mengetahui kelayakan per bagian bahan ajar, dan dihitung persentase keseluruhan untuk mengetahui kelayakan keseluruhan produk.Hasil perhitungan dikonsultasikan pada Tabel I untuk mengetahui kelayakan produk.Hasil perhitungan validasi ahli materi dan media tersaji dalam Tabel II

TABEL II

Hasil Validasi Bahan Ajar oleh Ahli

\begin{tabular}{clll}
\hline Bahan Ajar & $\begin{array}{l}\text { Aspek } \\
\text { Validasi }\end{array}$ & $\begin{array}{l}\text { Hasil } \\
\text { Validasi }\end{array}$ & Keterangan \\
\hline \multirow{2}{*}{ Buku Ajar } & Materi & $88,75 \%$ & $\begin{array}{l}\text { Layak dengan } \\
\text { predikat bagus }\end{array}$ \\
\cline { 2 - 4 } & Media & $93,75 \%$ & $\begin{array}{l}\text { Layak dengan } \\
\text { predikat bagus }\end{array}$ \\
\cline { 2 - 4 }
\end{tabular}

Penilaian oleh validator ahli materi dan media menunjukkan bahwa produk bahan ajar layak dan siap digunakan untuk pembelajaran pada matakuliah Teori dan Praktek Bola Voli II yang sebenarnya. Dari sisi kegrafikan/aspek media, buku ajar telah cukup memenuhi unsu kegrafikan yang baik, misalnya pada penataan gambar dan tulisan, warna tulisan, kelengkapan penyajian, dan sebagainya

Hasil validasi digunakan sebagai acuan untuk melaksanakan tahap revisi terhadap bahan ajar. Untuk aspek materi dan media, proses revisi buku ajar cetak didasarkan pada saran-saran tertulis yang telah diberikan oleh ahli/validator (Tabel III), karena berdasarkan hasil perhitungan, tiap aspek validasi memiliki kategori layak dengan predikat bagus/sangat bagus.

Selain memberikan penilaian dalam bentuk angka, validator juga memberikan penilaian dalam bentuk saran-saran untuk perbaikan buku ajar.Saran-saran tersebut terangkum dalam Tabel III TABEL III

Saran-saran Perbaikan Bahan Ajar oleh Validator

\begin{tabular}{ll}
\hline Validator & \multicolumn{1}{c}{ Saran yang dikemukakan } \\
\hline & a. Beberapa gambar ilustrasi kurang \\
& jelas termasuk sumbernya \\
& b. Rangkuman belum menunjukkan \\
Ahli & gambaran isi secara menyeluruh \\
Media & c. Huruf yang dipakai belum \\
& konsisten \\
& d. Secara umum, buku ajar telah \\
& memadai \\
\hline Ahli & a. Beberapa gambar ilustrasi kurang \\
Materi & jelas termasuk sumbernya \\
\hline
\end{tabular}



b. Rangkuman belum menunjukkan gambaran isi secara menyeluruh
c. Secara umum, buku ajar telah memadai

Saran-saran yang diberikan seperti tertera dalam Tabel III di atas juga sebagai bahan pertimbangan dalam melakukan revisi produk bahan ajar yang dikembangkan, penyesuaian-penyesuaian banyak dilakukan sesuai saran ahli sehingga produk akhir yang dikembangkan tidak hanya layak digunakan, namun juga baik untuk diterapkan dalam pembelajaran.

\section{Simpulan dan Saran}

Berdasarkan tahap penelitian yang telah dilakukan dapat ditarik kesimpulan antara lain hasil validasi untuk buku ajar cetak menurut ahli materi dan media berada pada kategori layak dengan predikat bagus $(93,75 \%$ untuk aspek media dan $88,75 \%$ untuk aspek materi), Revisi yang dilakukan terfokus pada buku ajar cetak, mencakup konsistensi jenis huruf, kualitas gambar ilustrasi beserta keterangannya, serta penyesuaian kompetensi dasar dan indikator kompetensi untuk matakuliah Teori dan Praktek Bola Voli II.

Saran-saran yang dapat dikemukakan untuk pelaksanaan penelitian selanjutnya yaitu perumusan kompetensi dasar dan indikator untuk penulisan buku ajar hendaknya mencakup tingkat kognitif rendah dan tinggi untuk melatih kemampuan kognitif mahasiswa, penyusunan buku ajar harus mampu membangkitkan motivasi mahasiswa untuk membaca dan mempelajarinya, salah satunya dengan memperbaiki kualitas gambar ilustrasi yang digunakan, Jumlah validator ahli untuk aspek materi, media, dan disarankan lebih dari satu orang agar memperleh lebih banyak saran dan masukan bagi perbaikan bahan ajar

\section{Daftar Pustaka}

Anggela, M. (2013). Masril. Yenni Darvina. Pengembangan Buku Ajar Bermuatan NilaiNilai Karakter pada Materi Usaha dan Momentum untuk Pembelajaran Fisika Siswa Kelas XI SMA. Jurnal Pillar of Physics Education, vol 1, 63-7063.

Anita, L. (2008). Kooperatif Learning.Jakarta: PT Grasindo.
Bajuri, P. (2016). Penerapan Alat Bantu Pembelajaran Untuk Meningkatkan Hasil Belajar Lompat Tinggi Gaya Straddle. Jurnal SPORTIF : Jurnal Penelitian Pembelajaran, 2(2), 67-75.

Dhias, F. W. P. (2013). Perkembangan Keseimbangan pada Anak Usia 7 s/d 12 Tahun Ditinjau dari Jenis Kelamin. Jurnal Media Ilmu Keolahragaan Indonesia 3(1), 25-29.

Ifadah, N. (2009). Metodologi Penulisan Ilmiah, Catatan Minngu ke-2, (Online), Available (http://http://noorifada.wordpress.com), diakses tanggal 12 Januari 2017

Muslich, M. (2009) KTSP (Kurikulum Tingkat Satuan Pendidikan): Dasar Pemahaman dan Pengembangan. Jakarta: PT. Bumi Aksara.

Mutohir, T.C. (2012) Permainan Bola voli Konsep Teknik Strategi dan Modifikasi. Jakarta:Graha Pustaka Media Utama.

Prastowo, A. (2011) PanduanKreatifMembuat Bahan Ajar Inovatif.Jogjakarta: Diva Press.

Rosdiani, D. (2013) Perencanaan Pembelajaran Dalam Pendidikan Jasmani danKesehatan. Bandung: CV Alfabeta.

Safitri, D ., Hartati .T. A. W. (2016). Kelayakan Aspek Media dan Bahasa dalam Pengembangan Buku Ajar dan Multimedia Interaktif Biologi Sel. Junal Florea Volume, 5(10), 6487-6516

Undang-Undang Republik Indonesia no 12. 2012. Pendidikan Tinggi. (Online). Available (http://www.kopertis12.or.id/wpcontent/uploads/2012/08/UU0122012_Full. pdf), diakses pada 16 Januari 2017.

Widyartono, D. (2010). Pengembangan Bahan Ajar Matakuliah Bahasa Indonesia dengan Web Interaktif. Thesis, Universitas Negeri Malang, PPs UM, Malang. 